\title{
Penyerapan Akar Gigi Apeks Luaran Hasil Rawatan Ortodontik Pada Enam dan 12 Bulan
}

(External Apical Root Resorption as a Result of Orthodontic Treatment at Six and 12 Months)

\author{
SHAHRUl Hisham ZAINAL ARIFFIn, Rus Dina Rus Din,ZUlHAM YAMAMOTO, IKMAL MOHAMAD JAAFAR, \\ SAHIDAN SENAFI \& ROHAYA MEGAT ABDUL WAHAB*
}

\begin{abstract}
ABSTRAK
Penyerapan akar gigi apeks luaran (PAAL) adalah salah satu kesan negatif semasa rawatan ortodontik selain daripada gigi yang mengalami trauma. Objektif kajian ini adalah untuk melihat hubungan antara sejarah trauma dan kejadian PAAL serta membandingkan tahap keterukan PAAL antara gigi trauma dan tanpa trauma selepas enam dan 12 bulan rawatan ortodontik. Sampel kajian merupakan gigi insisor tengah maksila daripada 23 subjek (8 lelaki dan 15 wanita berumur 12 hingga 26 tahun) dengan 19 mempunyai trauma (tanpa penyerapan akar gigi) dan 27 tanpa trauma. Rawatan ortodontik dilakukan dengan menggunakan dawai arkus NiTi 0.014", 0.018” dan 0.018” × 0.025" pada enam bulan pertama. Selepas enam bulan, rawatan ortodontik diteruskan dengan menggunakan dawai arkus keluli tahan karat saiz 0.019" × 0.025 " sehingga rawatan ortodontik mencapai satu tahun. PAAL gigi diukur melalui imej tomografi berkomputer pancaran-kon (CBCT) yang diambil sebelum $\left(X_{0}\right)$, selepas enam bulan $\left(X_{6}\right)$ dan selepas 12 bulan $\left(X_{12}\right)$ rawatan ortodontik. Penyerapan akar dikira dengan menolak panjang gigi pada $X_{6}$ dan $X_{12}$ dengan panjang gigi pada $X_{0}$. Kejadian PAAL dalam kumpulan trauma dan tanpa trauma masing-masing adalah $89.5 \%$ dan $77.8 \%$ (penyerapan akar rendah dari $2 \mathrm{~mm}$ ) selepas enam bulan rawatan ortodontik. Selepas 12 bulan rawatan ortodontik, semua gigi menunjukkan PAAL. Kejadian PAAL antara gigi trauma dan tanpa trauma tidak menunjukkan perbezaan yang signifikan ( $\mathrm{p}>0.05)$. Dalam kajian ini, gigi yang mengalami trauma serta tanpa trauma membentuk PAAL pada kadar yang sama selepas enam dan 12 bulan rawatan orthodontik. Oleh itu, adalah selamat untuk melakukan rawatan ortodontik kepada pesakit yang mempunyai sejarah trauma pada gigi.
\end{abstract}

Kata kunci: Insisor; ortodontik; penyerapan akar gigi; trauma pergigian

ABSTRACT

External apical root resorption (EARR) is one of the negative effects of orthodontic treatment apart from dental trauma. The objectives of this study were to observed the relationship between history of trauma and the occurence of EARR and also to compare the severity of EARR between traumatized and nontraumatized teeth during six and 12 months of orthodontic treatment. The sample of study was maxilla central incisor from 23 subjects ( 8 male and 15 female age 12 to 26 years old) in which 19 with traumatized teeth (without root resorption) and 27 nontraumatized teeth. Orthodontic treatment used 0.014 ", 0.018" and 0.018" $\times 0.025$ " NiTi archwires for the first six months. After six months, orthodontic treatment was continued using 0.019" $\times 0.025$ " stainless steel arch wire until the treatment reached one year. EARR was measured using cone beam computed tomography (CBCT) images that was taken before $\left(X_{0}\right)$, after six months $\left(X_{6}\right)$ and after 12 months $\left(X_{12}\right)$ of orthodontic treatment. Root resorption was calculated by substracting tooth length at $X_{6}$ and $X_{12}$ with tooth length at $X_{0}$. The incidence of EARR in traumatised and non-traumatised teeth group were each $89.5 \%$ and $77.8 \%$, respectively (root resorption less than $2 \mathrm{~mm}$ ) after six months of orthodontic treatment. After 12 months of orthodontic treatment, all teeth showed EARR. There is no significant difference in the occurence of EARR between traumatized and nontraumatized teeth $(\mathrm{p}>0.05)$. In this study, traumatized and nontraumatized teeth develop EARR at the same rate after six and 12 months of orthodontic treatment. Hence, it is safe to do an orthodontic treatment to patients with dental trauma history.

Keywords: Dental trauma; incisor; orthodontic; root resorption

\section{PENDAHULUAN}

Rawatan ortodontik merupakan rawatan yang diberikan oleh pakar ortodontik dengan mengenakan daya ortodontik pada gigi menggunakan dawai arkus bagi merapikan gigi yang tidak tersusun. Pergerakan gigi akibat rawatan ortodontik boleh membawa kesan negatif kepada pesakit. Antara kesan negatif rawatan ortodontik ialah perubahan pulpa gigi, penyakit periodontal, pengurangan kalsium dalam tulang alveolar, penyerapan akar gigi dan disfungsi pada temporomandibular (Talic 2011).

Pada tahap akut, rawatan ortodontik boleh menyebabkan kesakitan dan keradangan gusi (Erdinç \& Dinçer 2004; Long et al. 2013; Tecco et al. 2009), mengganggu pertuturan (Long et al. 2013) dan menyebabkan penyakit periodontal (Karkhanechi et al. 2013). Walau bagaimanapun, kajian terhadap kesan jangka 
masa panjang rawatan ortodontik menunjukkan tiada perbezaan yang ketara dalam kejadian karies, penyakit periodontal atau kehilangan gigi antara individu yang mendapatkan dan tidak mendapatkan rawatan ortodontik (Thomson 2002) . Kesan rawatan ortodontik yang paling ketara adalah penyerapan akar gigi (Castro et al. 2015, 2013; Lund et al. 2010). Antara penyerapan akar gigi yang paling kerap berlaku semasa rawatan ortodontik adalah jenis penyerapan akar apeks luaran (PAAL) (Topkara et al. 2012). PAAL menyebabkan hakisan pada akar gigi yang menjurus kepada kehilangan bahan daripada lapisan dentin atau cementum. Kebiasaannya, penyerapan akar gigi berlaku pada tahap minimum semasa rawatan ortodontik, walau bagaimanapun, PAAL pada tahap yang teruk boleh menyebabkan gigi tertanggal.

Penyerapan akar gigi boleh berlaku seawal peringkat meratakan gigi semasa rawatan ortodontik (Smale et al. 2005). Perkaitan antara keterukan penyerapan akar gigi pada bulan keenam dan 12 rawatan ortodontik membolehkan pengenalpastian awal terhadap risiko penyerapan akar yang lebih teruk pada seseorang individu (Artun et al. 2005). Terdapat beberapa faktor berlakunya PAAL yang didorong oleh rawatan ortodontik dan ia terdiri daripada faktor variasi biologi dan faktor rawatan itu sendiri seperti morfologi akar gigi (Sameshima \& Sinclair 2001), genetik (Al-Qawasmi et al. 2003), sejarah trauma (Linge \& Linge 1991; Nanekrungsan et al. 2012), jangka masa rawatan dan magnitud daya ortodontik yang dikenakan (Fox 2005; Levander \& Malmgren 1988).

Gigi insisor merupakan antara jenis gigi yang mudah mengalami penyerapan akar gigi (Castro et al. 2013). Oleh kerana trauma merupakan salah satu faktor etiologikal yang boleh menyebabkan tahap penyerapan akar gigi yang serius, trauma pada gigi perlu sentiasa dinilai dengan teliti oleh pakar ortodontik sebelum meneruskan rawatan ortodontik (Lopatiene \& Dumbravaite 2008). Penilaian trauma juga penting untuk mengurangkan komplikasi rawatan ortodontik (Luther et al. 2005). Trauma kepada insisor maksila adalah perkara biasa dan berkaitan dengan peningkatan overjet. Oleh itu, ramai pesakit ortodontik akan mempunyai insisor yang pernah mengalami trauma. Tambahan pula, apabila suatu trauma menyebabkan beban kepada satu insisor maksila, $45 \%$ daripada gigi berkaitan akan mengalami trauma pada masa yang sama (Luther et al. 2005).

Rawatan ortodontik pada gigi yang telah mengalami trauma mempunyai risiko penyerapan akar gigi yang lebih tinggi berbanding gigi normal. Ini kerana, penyerapan akar gigi semasa trauma menyebabkan ia lebih mudah mengalami kehilangan bahan akar gigi (protein dan mineral) ketika rawatan ortodontik (Lopatiene \& Dumbravaite 2008). Oleh itu, kajian ini bertujuan untuk menilai hubungan antara sejarah trauma pergigian dengan pembentukan penyerapan akar gigi semasa rawatan ortodontik dan membandingkan keterukan penyerapan akar gigi antara gigi insisor tengah maksila trauma dengan tanpa trauma selepas enam dan 12 bulan rawatan ortodontik menggunakan tomografi berkomputer pancaran kon (СBCT).
Pemeriksaan in vivo terhadap penyerapan akar gigi boleh dilakukan menggunakan radiografi 2-dimensi (2D) seperti filem periapeks, panoramik, sefalogram lateral dan kaedah terbaru dengan imej 3-dimensi (3D) seperti tomografi berkomputer (CT) serta СВCT. Secara amnya, radiografi 2D menggunakan radiasi tahap rendah dan mudah didapati berbanding pengimbas 3D. Walau bagaimanapun, radiografi $2 \mathrm{D}$ cenderung mengalami ralat kedudukan, herotan dan pertindihtepatan yang menjurus kepada anggaran panjang gigi berlebihan atau berkurangan (Brezniak et al. 2004; Leach et al. 2001). Oleh itu, pengimbasan 3D adalah lebih tepat dalam pengukuran panjang akar gigi.

Selain itu, penggunaan CT juga pernah digunakan dalam kajian yang melibatkan penyerapan akar gigi (Da Silveira et al. 2007; Ericson \& Kurol 2000). Walau bagaimanapun, ia melibatkan penggunaan dos radiasi yang tinggi dan mahal berbanding kaedah sedia ada lain. Perkembangan СВСТ menghasilkan imej tanpa herotan serta mempunyai resolusi yang tinggi (Lund et al. 2010) serta dos radiasi yang rendah berbanding CT (Tsiklakis et al. 2005) dan tidak terlalu mahal. Oleh itu, CBCT telah mula digunakan bagi mengkaji penyerapan akar gigi (Alqerban et al. 2011; Lund et al. 2010; Yu et al. 2012).

\section{BAHAN DAN KAEDAH}

\section{PEMILIHAN SUBJEK}

Bagi mengkaji kesan trauma gigi kepada penyerapan akar gigi semasa rawatan ortodontik, satu kajian kohort prospektif dilakukan. Subjek kajian diambil pada Oktober 2012 - Mac 2015 serta dipilih daripada kalangan pesakit yang mendapatkan rawatan di Jabatan Ortodontik, Fakulti Pergigian, Universiti Kebangsaan Malaysia di Kuala Lumpur. Seramai 23 pesakit ortodontik yang terdiri daripada 15 perempuan dan 8 lelaki (purata umur: 17.6 tahun \pm 3.99 ; julat 12.2 - 26.6 tahun) dikaji. Sampel terdiri daripada 46 insisor tengah maksila dengan 19 batang gigi mempunyai sejarah trauma dan 27 batang tanpa trauma. Jumlah sampel ditentukan dengan menggunakan formula pengiraan saiz sampel untuk penyelidikan kohort (Kasiulevicius et al. 2006) iaitu:

$$
n 1=n 2=\frac{\left(Z_{\alpha} \sqrt{2 p q}+Z_{\beta} \sqrt{p_{1} q_{1}+p_{2} q_{2}}\right)^{2}}{(\Delta p)^{2}}
$$

Kriteria penglibatan dan penyingkiran digunakan untuk memilih subjek yang sesuai untuk diambil sebagai sampel kajian (Jadual 1). Trauma pada gigi insisor maksila setiap subjek dipertimbangkan berdasarkan sejarah individu, ujian klinikal dan radiograf periapeks. Ujian klinikal dilakukan untuk menilai kewujudan bengkak pada gusi, perubahan warna gigi, rekahan gigi, patah, perkusi gigi dan mobiliti gigi. Imej radiograf periapeks juga dirakamkan untuk menilai sama ada gigi mengalami 
JADUAL 1. Kriteria penglibatan dan penyingkiran subjek kajian

\begin{tabular}{l}
\hline Parameter \\
\hline Kriteria Penglibatan Subjek \\
1. Kesihatan umum dan periodontal yang baik \\
2. Tidak hamil \\
3. Tidak mengambil sebarang ubat anti-radang pada bulan sebelum dan semasa kajian atau \\
terapi antibiotik dalam tempoh enam bulan sebelum rawatan ortodontik \\
4. Mempunyai kebersihan mulut yang sangat baik \\
5. Tidak mendapatkan rawatan ortodontik atau ortopedik pada maksila dan mandibel sebelum \\
kajian \\
7. Tiada anomali kraniofasial \\
8. Tiada bukti radiografik kehilangan tulang periodontal \\
9. Mempunyai satu insisor tengah maksila yang mempunyai sejarah trauma dan satu insisor \\
Kriteria Penyingkiran Subjek \\
1. Pernah mendapat rawatan ortodontik \\
2. Insisor maksila sudah tidak hidup (non-vital) atau telah tiada \\
3. Akar gigi insisor maksila sudah pernah dirawat endodontik \\
4. Akar gigi insisor maksila patah \\
5. Gigi insisor maksila mengalami ankilosis
\end{tabular}

patah akar gigi atau penyerapan akar. Persetujuan secara bertulis diperoleh daripada setiap subjek atau ibu bapa subjek (untuk subjek berusia kurang 18 tahun) untuk terlibat sebagai sampel kajian. Kelulusan etika kajian ini diperoleh daripada Jawatankuasa Etika Penyelidikan Universiti Kebangsaan Malaysia (No. UKM1.5.3.5/244/ ERGS/1/2012/SKK11/UKM/02/05).

\section{RAWATAN ORTODONTIK}

Rawatan ortodontik untuk enam bulan pertama adalah menggunakan dawai arkus jenis Nikel titanium (NiTi) yang bersaiz 0.014", 0.018" dan 0.018" × 0.025". Bagi sesi rawatan ortodontik enam bulan seterusnya, dawai arkus jenis keluli tahan karat bersaiz 0.019 " $\times 0.025$ " telah digunakan. Penggantian dawai arkus ditentukan secara klinikal selepas menilai tahap kelurusan gigi.

\section{UJIAN CBCT}

Teknik imbasan tomografi komputeran pancaran-kon (СВCT), Kodak 9000 3D, Carestream Health) telah digunakan terhadap setiap subjek bagi memperoleh imej insisor tengah maksila sebelum $\left(\mathrm{X}_{0}\right)$, selepas enam bulan $\left(\mathrm{X}_{6}\right)$ dan selepas 12 bulan $\left(\mathrm{X}_{12}\right.$ rawatan ortodontik. Peralatan СBCT telah digunakan untuk memperoleh imej 3D kawasan insisor tengah maksila dengan isi padu piksel (voxel) saiz $0.2 \mathrm{~mm}^{3}$, bidang pandang $5 \times 5 \mathrm{~cm}, 65 \mathrm{kVp}, 8$ $\mathrm{mA}$ dan masa perolehan $9.7 \mathrm{~s}$. Dos yang berkesan dalam imbasan kawasan ini adalah 19 - 40 microsieverts $[\mathrm{mSv}]$ (American Academy of Oral and Maxillofacial Radiology 2013). Fail pengimejan digital dan analisis (The digital imaging and communications in medicine, DICOM) masing- masing dilihat dan dinilai menggunakan perisian CS 3D (Carestream Health Inc., Jerman) untuk pengukuran linear panjang gigi.

Orientasi imej dan pengukuran panjang gigi (dalam $\mathrm{mm}$ ) dijalankan seperti kaedah yang diterangkan oleh Sherrard et al. (2010):

Dalam pandangan sagital, satah paksi ditempatkan pada tahap temuan simentoenamel (CEJ; cementoenamel junction) labial gigi yang diukur, dengan CEJ akan menghilang dalam pandangan paksi; dalam pandangan paksi, satah sagital ditempatkan untuk bertemu di tengah-tengah ruang pulpa; dalam pandangan sagital, satah korona dipindahkan dan diputarkan untuk bertemu dengan hujung insisal dan hujung akar (apeks). Satah paksi dipindahkan untuk memotong CEJ labial; dalam pandangan paksi, satah sagital dipindahkan atau diputar untuk memotong permukaan labial dan palatal pada gigi dan pusat ruang pulpa. Satah korona dipindahkan untuk memotong permukaan mesial dan distal gigi dan pusat ruang pulpa; dalam pandangan korona, satah sagital diputar untuk menyilang apeks dan pusat ruang pulpa pada tahap CEJ labial; dan dalam pandangan sagital, panjang gigi diukur dari bahagian hujung insisal ke apeks akar. Gerakkan satah paksi dalam pandangan sagital, sambil perhatikan pandangan paksi sehingga titik sebelum struktur gigi menghilang membenarkan pengenalpastian hujung insisal dan apeks akar (Rajah 1).

Penyerapan akar gigi diukur dengan membezakan panjang gigi pada $X_{6}$ dan $X_{12}$ dengan panjang gigi $X_{0}$. Pengukuran panjang gigi dilakukan sebanyak tiga kali. Nilai korelasi intra-kelas (ICC) diperoleh dengan menggunakan formula Dahlberg bagi menentukan kebolehpercayaan intra pemeriksa (Galvão et al. 2012). 


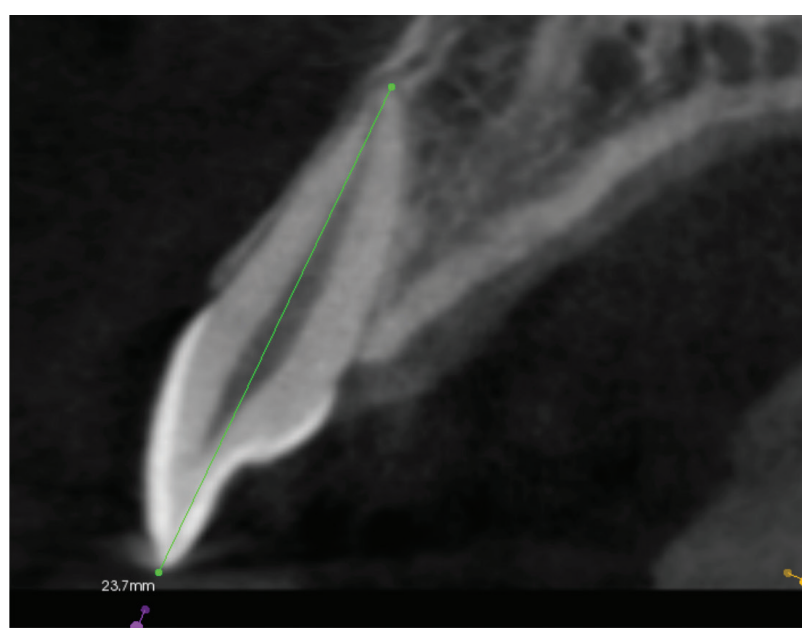

RAJAH 1. Pengukuran panjang gigi dari pandangan sagital menggunakan perisian CS 3D

\section{ANALISIS STATISTIK}

Data yang diperoleh adalah data demografik subjek dan data penyerapan akar gigi yang dianalisis menggunakan perisian SPSS versi 22. Taburan data dianalisis menggunakan ujian normaliti Shapiro-Wilk. Ujian Pearson's chi-square $(\alpha=0.05)$ digunakan untuk menilai sama ada sejarah trauma berkaitan atau tidak dengan kejadian penyerapan akar gigi semasa enam bulan rawatan ortodontik. Ujian bukan parametrik Mann-Whitney $U$ dilakukan untuk menganalisis perbezaan penyerapan akar gigi antara kumpulan trauma dan tanpa trauma pada $\mathrm{X}_{6}$ dan $\mathrm{X}_{12}$.

\section{HASIL PENYELIDIKAN}

Nilai ICC antara dua pengukuran panjang gigi ialah 0.95 , dengan 95\% selang keyakinan (CI). Ini menunjukkan tiada perbezaan antara kedua pengukuran panjang gigi oleh penyelidik. Oleh itu, teknik yang digunakan untuk mengukur panjang gigi boleh diulang.

Kesemua sampel gigi tidak menunjukkan penyerapan akar gigi pada $\mathrm{X}_{0}$. Pada $\mathrm{X}_{6}, 77.8 \%(n=21)$ daripada 27 insisor tengah maksila pada kumpulan yang mempunyai gigi tanpa trauma membentuk PAAL dan $22.2 \%(n=6)$ tidak menunjukkan PAAL. Daripada 19 insisor tengah maksila bagi kumpulan yang mempunyai gigi trauma, penyerapan akar gigi terjadi sebanyak $89.5 \%(n=17)$, manakala $5.6 \%$ $(n=2)$ tidak menunjukkan penyerapan akar gigi (Rajah 2). Walaupun kebanyakan gigi yang mempunyai trauma membentuk penyerapan akar gigi pada $\mathrm{X}_{6}$ berbanding gigi tanpa trauma, analisis statistik melalui ujian khi kuasa dua tidak menunjukkan perbezaan yang signifikan $(p>0.05)$. Oleh itu, gigi yang mengalami trauma dan gigi tanpa trauma menunjukkan kejadian penyerapan akar gigi pada tahap yang sama semasa enam bulan rawatan ortodontik (Rajah 2; $\mathrm{X}_{6}$ ). Walau bagaimanapun, pada 12 bulan $\left(\mathrm{X}_{12}\right)$ rawatan ortodontik analisis statistik tidak dilakukan kerana kesemua gigi insisor tengah maksila yang mengalami PAAL telah meningkat kepada $100 \%$ berbanding rawatan sebelumnya $\left(\mathrm{X}_{6}\right)$ iaitu $77.8 \%$ dan $89.5 \%$ masing-masing pada gigi tanpa trauma dan trauma (Rajah 2).

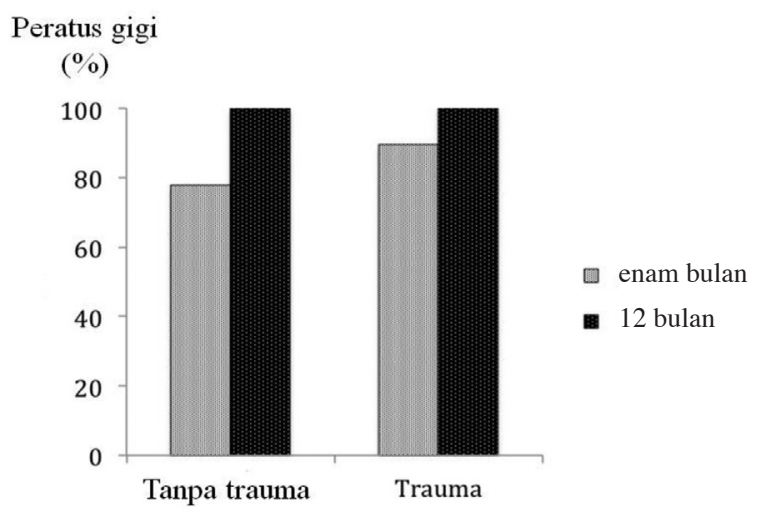

RAJAH 2. Peratus gigi yang mengalami PAAL pada kumpulan trauma dan tanpa trauma selepas enam dan 12 bulan rawatan ortodontik. Perbezaan PAAL bagi kumpulan tanpa trauma dan trauma pada enam bulan rawatan ortodontik adalah tidak signifikan $(p>0.05)$. Pada 12 bulan rawatan ortodontik, PAAL meningkat $100 \%$ daripada $77.8 \%$ (tanpa trauma) dan $89.5 \%$ (trauma)

Kejadian PAAL pada kumpulan trauma dan tanpa trauma seiring dengan peningkatan tempoh masa rawatan ortodontik dari enam hingga 12 bulan (Jadual 2). Purata penyerapan akar gigi adalah $0.31 \pm 0.29 \mathrm{~mm}$ bagi gigi trauma dan $0.31 \pm 0.30 \mathrm{~mm}$ bagi gigi tanpa trauma selepas enam bulan rawatan ortodontik (Jadual 2). Manakala, pada bulan ke 12 rawatan ortodontik, purata penyerapan akar gigi adalah $0.9 \pm 0.61 \mathrm{~mm}$ bagi gigi trauma dan $0.87 \pm$ $0.46 \mathrm{~mm}$ bagi gigi tanpa trauma (Jadual 2). Seterusnya, kumpulan trauma menunjukkan median PAAL yang rendah $(0.20 \mathrm{~mm})$ berbanding kumpulan tanpa trauma $(0.25 \mathrm{~mm})$ pada $X_{6}$, sebaliknya pada $X_{12}$ PAAL kumpulan trauma $(0.80$ $\mathrm{mm}$ ) melebihi kumpulan tanpa trauma $(0.75 \mathrm{~mm})$ (Jadual 2). Walau bagaimanapun, analisis statistik Mann-Whitney U tidak menunjukkan perbezaan yang signifikan terhadap kejadian PAAL antara kumpulan trauma dan tanpa trauma pada enam dan 12 bulan rawatan ortodontik $(p>0.05)$ (Jadual 3). Ini menunjukkan tiada perbezaan yang ketara pada kejadian PAAL antara kumpulan gigi trauma dan tanpa trauma bagi kedua tempoh rawatan ortodontik iaitu enam bulan $\left(\mathrm{X}_{6}\right)$ dan 12 bulan $\left(\mathrm{X}_{12}\right)$.

Sebanyak lapan insisor tengah maksila daripada kumpulan trauma dan tanpa trauma tidak menunjukkan PAAL pada $\mathrm{X}_{6}$. Kesemua gigi mengalami penyerapan akar gigi kurang daripada $2 \mathrm{~mm}$ selepas enam bulan rawatan ortodontik. Semasa bulan ke 12 rawatan ortodontik, majoriti insisor tengah maksila juga menunjukkan penyerapan akar gigi kurang daripada $2 \mathrm{~mm}$. Hanya satu insisor masing-masing daripada gigi trauma dan tanpa trauma menunjukkan penyerapan akar gigi melebihi 2 mm (Jadual 4). Ini menunjukkan tahap keterukan PAAL meningkat seiring dengan tempoh rawatan ortodontik iaitu enam dan 12 bulan kerana kesemua gigi mengalami 
JADUAL 2. Statistik diskriptif PAAL bagi kumpulan gigi trauma dan tanpa trauma pada enam dan 12 bulan rawatan ortodontik

\begin{tabular}{lcccccccc}
\hline Kumpulan gigi & $\mathrm{n}$ & Peringkat & $\begin{array}{c}\text { Median } \\
(\mathrm{mm})\end{array}$ & IQR & Purata (mm) & S.D. & Min (mm) & $\begin{array}{c}\text { Maks } \\
(\mathrm{mm})\end{array}$ \\
\hline \multirow{2}{*}{ Tanpa trauma } & 27 & $\mathrm{X}_{6}$ & 0.25 & 0.45 & 0.31 & 0.30 & 0 & 1.10 \\
& & $\mathrm{X}_{12}$ & 0.75 & 0.60 & 0.87 & 0.46 & 0.20 & 2.00 \\
Trauma & \multirow{2}{*}{19} & $\mathrm{X}_{6}$ & 0.20 & 0.30 & 0.31 & 0.29 & 0 & 1.05 \\
& & $\mathrm{X}_{12}$ & 0.80 & 0.95 & 0.90 & 0.61 & 0.10 & 2.25 \\
\hline
\end{tabular}

IQR=Interquartile range

JADUAL 3. Perbandingan PAAL di antara kumpulan trauma dan tanpa trauma pada enam $\left(\mathrm{X}_{6}\right)$ dan 12 bulan $\left(\mathrm{X}_{12}\right)$ rawatan ortodontik menggunakan ujian Mann-Whitney $U$

\begin{tabular}{lcccc}
\hline Kumpulan gigi & $\mathrm{n}$ & Peringkat & Mean rank & Nilai $\mathrm{p}$ \\
\hline Tanpa trauma & 27 & $\mathrm{~T} 2$ & 23.33 & 0.920 \\
Trauma & 19 & $\mathrm{~T} 2$ & 23.74 & 0.911 \\
Tanpa trauma & 27 & T3 & 23.69 & \\
Trauma & 19 & T3 & 23.24 & \\
\hline
\end{tabular}

Tiada perbezaan yang signifikan $(p>0.05)$ terhadap kejadian PAAL pada kumpulan trauma dan tanpa trauma pada enam dan 12 bulan rawatan ortodontik

JADUAL 4. Bilangan dan peratusan gigi dan keterukan penyerapan akar gigi pada enam $\left(\mathrm{X}_{6}\right)$ dan 12 bulan $\left(\mathrm{X}_{12}\right)$ rawatan ortodontik

\begin{tabular}{lcccccccc}
\hline & \multicolumn{3}{c}{$\mathrm{X}_{6}$} & \multicolumn{4}{c}{$\mathrm{X}_{12}$} \\
\cline { 2 - 10 } & \multicolumn{2}{c}{ Tanpa trauma } & \multicolumn{2}{c}{ Trauma } & \multicolumn{2}{c}{ Tanpa trauma } & \multicolumn{2}{c}{ Trauma } \\
\cline { 2 - 9 } & $\mathrm{n}$ & $\%$ & $\mathrm{n}$ & $\%$ & $\mathrm{n}$ & $\%$ & $\mathrm{n}$ & $\%$ \\
\hline $0 \mathrm{~mm}$ & 6 & 22.2 & 2 & 10.5 & - & - & - & - \\
$0.1-0.9 \mathrm{~mm}$ & 20 & 74.1 & 16 & 84.2 & 19 & 70.4 & 12 & 63.2 \\
$1.0-1.9 \mathrm{~mm}$ & 1 & 3.7 & 1 & 5.3 & 7 & 25.9 & 6 & 31.6 \\
$>2 \mathrm{~mm}$ & - & & - & - & 1 & 3.7 & 1 & 5.2 \\
\hline
\end{tabular}

penyerapan akar pada bulan ke 12. Walau bagaimanapun, tahap keterukan PAAL adalah hampir sama antara kumpulan gigi trauma dengan tanpa trauma kerana hanya satu gigi insisor dalam setiap kumpulan mengalami penyerapan akar lebih $2 \mathrm{~mm}$.

\section{PERBINCANGAN}

Kajian ini menggunakan gigi insisor tengah maksila kerana insisor merupakan gigi yang mudah terdedah kepada penyerapan akar gigi (Abass \& Hartsfield 2007). Penyerapan akar gigi hanya berlaku kepada 5-10\% daripada subjek yang tidak pernah mendapat rawatan ortodontik (Consolaro \& Furquim 2014). Hal ini berlaku kerana gigi mengalami aliran distal (mesial drift) oleh daya oklusal (Tsuchiya et al.2013). Insisor tengah maksila mempunyai peratusan tertinggi untuk berlakunya tahap penyerapan akar gigi yang teruk, diikuti dengan insisor lateral maksila dan insisor lateral mandibel (Maués et al. 2015). Insisor juga mudah mengalami penyerapan akar semasa rawatan ortodontik. Dengan melakukan analisis terhadap imej radiograf periapeks, Lupi et al. (1996) melaporkan bahawa bilangan insisor yang menunjukkan penyerapan akar gigi meningkat daripada $15 \%$ sebelum rawatan ortodontik kepada $73 \%$ selepas rawatan ortodontik.

Penyerapan akar gigi insisor dalam kajian ini adalah lebih tinggi daripada yang dilaporkan oleh Lupi et al. (1996) iaitu mencapai $80 \%$ selepas enam bulan rawatan ortodontik (Rajah 2). Penyerapan akar yang lebih tinggi dalam kajian ini mungkin disebabkan oleh penggunaan СBCT yang lebih sensitif daripada radiografi intra oral seperti yang telah dilakukan oleh Lupi et al. (1996) dalam mengesan penyerapan akar gigi (Patel et al. 2009). СВСТ juga didapati lebih tepat daripada kaedah radiografi panoramik (Dudic et al. 2009; Topkara et al. 2012) dan radiografi periapeks (Sameshima \& Sinclair 2001).

Kajian ini melaporkan kejadian PAAL insisor yang lebih rendah berbanding kajian terdahulu (Maltha et al. 2004; Owman-Moll 1995). Kajian oleh Maltha et al. (2004) dengan menggunakan molar ketiga rahang anjing dewasa, mendapati bahawa selepas 14-17 minggu penggunaan daya ortodontik, 94\% daripada permukaan akar dalam kawasan tekanan mengalami penyerapan. Owman-Moll (1995) pula mendapati bahawa kes penyerapan akar pada pramolar pertama atau kedua maksila remaja yang 
digerakkan ke arah bukal mencecah sehingga 93\%. Gigi insisor dan gigi molar mempunyai bilangan akar gigi yang berbeza iaitu masing-masing satu dan dua akar gigi. Walau bagaimanapun, morfologi gigi bukan faktor yang menyebabkan penyerapan akar gigi semasa rawatan ortodontik (Weltman et al. 2010).

Pengaruh sejarah trauma pergigian terhadap penyerapan akar gigi semasa rawatan ortodontik telah lama dikaji (Brin et al. 2003; Linge \& Linge 1991, 1983; Mandall et al. 2006; Nanekrungsan et al. 2012). Walau bagaimanapun, perbezaan teknik pengukuran antara kajian terdahulu menyebabkan kesukaran dalam membandingkan kekerapan dan keterukan PAAL. Dalam kajian ini, tiada perbezaan yang signifikan $(p>0.05)$ antara kumpulan gigi trauma dan tanpa trauma dengan purata penyerapan akar gigi iaitu $0.31 \pm 0.29 \mathrm{~mm}$ bagi gigi trauma dan $0.31 \pm 0.30 \mathrm{~mm}$ bagi gigi tanpa trauma selepas enam bulan rawatan ortodontik, serta pada bulan ke 12 rawatan ortodontik, dengan purata penyerapan akar gigi adalah $0.9 \pm 0.61 \mathrm{~mm}$ bagi gigi trauma dan $0.87 \pm$ $0.46 \mathrm{~mm}$ bagi gigi tanpa trauma juga menunjukkan tiada perbezaan yang signifikan $(p>0.05)$ antara kumpulan trauma dan tanpa trauma. Walau bagaimanapun, Linge dan Linge (1983) telah mengkaji kejadian PAAL dengan mengukur perubahan purata pada panjang akar gigi bagi gigi trauma dan tanpa trauma pada bulan ke 43 (3.6 tahun) rawatan ortodontik. Dalam kajian ini, $1.07 \pm 1.19 \mathrm{~mm}$ purata penyerapan akar gigi telah direkod bagi kumpulan trauma berbanding $0.64 \pm 1.04 \mathrm{~mm}$ bagi kumpulan tanpa trauma dan perbezaan ini adalah signifikan $(p<0.05)$ (Linge \& Linge 1983). Keterukan yang lebih tinggi pada penyerapan akar gigi trauma dapat diperhatikan dalam kajian Linge dan Linge (1983) telah pengukuran dilakukan pada penghujung rawatan ortodontik (purata 3.6 tahun) menggunakan radiograf periapeks, manakala dalam kajian ini pengukuran penyerapan akar gigi dilakukan pada peringkat awal rawatan ortodontik iaitu enam dan 12 bulan menggunakan imej СBCT yang terhasil merupakan pendekatan yang lebih tepat kerana mempunyai resolusi yang lebih baik berbanding imej periapeks.

Nanekrungsan et al. (2012) mengkaji faktor berkaitan dengan PAAL termasuklah trauma dan terdapat perbezaan yang signifikan $(p<0.05)$ pada peratus PAAL antara gigi yang mempunyai sejarah trauma (25 batang; $14.75 \%$ ) dan gigi tanpa trauma (539 batang; $8.07 \%$ ) pada penghujung rawatan ortodontik. Sebaliknya, dalam kajian ini, purata penyerapan akar gigi bagi kumpulan trauma dan tanpa trauma tidak menunjukkan perbezaan yang signifikan $(p>0.05)$ pada enam $\left(\mathrm{X}_{6}\right)$ dan $12\left(\mathrm{X}_{12}\right)$ bulan rawatan ortodontik (Jadual 3). Kesemua gigi insisor dalam kajian ini tidak menunjukkan kehadiran penyerapan akar gigi pada imej radiograf sebelum rawatan dimulakan iaitu $\mathrm{X}_{0}$. Hasil kajian ini adalah konsisten dengan hasil kajian Malmgren et al. (1982) dan beliau mendapati gigi trauma mempunyai ligamen periodontal yang masih utuh serta memberikan prognosis setanding dengan gigi normal semasa rawatan ortodontik.
Pendedahan kepada penyerapan akar gigi semasa rawatan ortodontik mungkin berkaitan dengan pelbagai faktor. Morfologi akar adalah salah satu faktor yang menyumbang kepada penyerapan akar (Oliveira et al. 2011). Insisor maksila dengan akar yang panjang, sempit dan menyimpang mempunyai risiko yang tinggi terhadap penyerapan akar gigi sepanjang tempoh tahap perataan awal dalam rawatan ortodontik (Smale et al. 2005). Tanda penyerapan akar gigi sebelum rawatan ortodontik seperti kontur akar tidak teratur meninggikan kemungkinan berlakunya penyerapan akar gigi semasa rawatan ortodontik (Leach et al. 2001; Malmgren et al. 1982).

Selain itu, kajian terdahulu mendapati kadar tekanan ortodontik yang dikenakan kepada gigi mempengaruhi penyerapan akar gigi (Topkara et al. 2012). Kajian yang dilakukan oleh Martins et al. (2012) mendapati gigi yang mengalami intrusi ditambah dengan pergerakan gigi anterior menunjukkan penyerapan akar gigi insisor yang lebih teruk berbanding gigi yang mengalami pergerakan gigi anterior tanpa intrusi. Selain itu, Han et al. (2005) menyimpulkan bahawa intrusi gigi menyebabkan penyerapan akar gigi berbanding ekstrusi gigi. Walau bagaimanapun, dalam kajian ini, tiada intrusi dan ekstrusi gigi serta pertindihan gigi berada pada tahap yang sederhana atau rendah.

Dalam kajian ini, pesakit yang dikaji berumur antara 12 dan 26 tahun dengan had umur pertumbuhan akar adalah pada umur 11.5 tahun (Linge \& Linge 1991). Selepas umur 11.5 tahun, akar gigi insisor maksila telah terbentuk dengan lengkap (Linge \& Linge 1983). Oleh itu, dalam kajian ini pengukuran panjang gigi tidak dipengaruhi oleh sebarang pertumbuhan akar yang berupaya memberi kesan pada ketepatan pengukuran penyerapan akar gigi kerana umur minima telah dihadkan pada 12 tahun.

Terdapat kajian terdahulu mengenai hubungan positif antara umur individu dan penyerapan akar gigi disebabkan rawatan ortodontik (Linge \& Linge 1983). Walau bagaimanapun, penyelidik selepas itu mendapati umur merupakan faktor yang tidak signifikan dalam berlakunya penyerapan akar gigi semasa rawatan ortodontik (Thongudomporn \& Freer 1998; Weiland 2003). Selain itu, tiada hubungan yang signifikan antara jantina dan penyerapan akar gigi (Beck \& Harris 1994). Oleh itu, individu 8 lelaki dan 15 perempuan dalam kajian ini telah digabungkan bagi tujuan analisis statistik.

Pelbagai faktor lain juga dilaporkan tidak berkesan dalam penentuan penyerapan akar gigi semasa rawatan ortodontik. Oliveira (2011) melaporkan bahawa peningkatan overjet dan overbite tidak berkaitan dengan penyerapan akar gigi. Oleh itu, pelbagai tahap maloklusi daripada subjek didapati tidak memberikan sebarang kesan kepada penyerapan akar. Tambahan pula, gigi yang mengalami trauma didapati tidak memberi kesan kepada kekuatan serta penyerapan akar gigi kerana tiada penyerapan akar yang dapat diperhatikan antara gigi yang tidak rosak dengan gigi yang pernah melalui rawatan endodontik (Esteves et al. 2007; Oliveira et al. 2011). Urutan dawai arkus dalam rawatan ortodontik 
juga dilaporkan tidak memberi sebarang kesan kepada penyerapan akar gigi (Mandall et al. 2006).

Dalam kajian ini, pendekatan bagi mengukur penyerapan akar gigi diseragamkan dengan mengubah suai kaedah daripada kajian yang dijalankan terhadap gigi khinzir (Sherrard et al. 2010). Pengubahsuaian ini adalah untuk memastikan panjang gigi pada sebelum rawatan ortodontik dan selepas enam serta 12 bulan rawatan ortodontik diukur pada titik rujukan yang sama dan pada sepanjang paksi yang sama tanpa perlu menformatkan semula atau memotong sebahagian atau kesemua imej untuk menyeragamkan orientasi. Ralat pengukuran dalam kajian ini adalah $0.35 \mathrm{~mm}$ iaitu sama dengan kajian Lund et al. (2010) yang juga merekodkan ralat kurang daripada 0.35 $\mathrm{mm}$ daripada pengukuran panjang gigi selepas pembinaan semula imej sekunder. Panjang gigi diukur dari hujung insisal hingga apeks akar gigi bagi meminimumkan ralat disebabkan artifak seperti pendakap ortodontik logam, dawai ortodontik dan bands yang akan mempengaruhi pengesanan CEJ (Sanders et al. 2007).

Resolusi imej boleh memberi kesan pada kejituan ukuran penyerapan akar gigi. Liedke et al. (2009) telah mengukur 59 batang gigi daripada imej yang diambil dengan tomografi iCAT pada resolusi isi padu piksel 0.4 , 0.3 dan $0.2 \mathrm{~mm}$. Beliau mendapati CBCT merupakan pendekatan yang boleh dipercayai untuk menganalisis penyerapan akar gigi sekiranya resolusi isi padu piksel kurang daripada $0.3 \mathrm{~mm}$. Saiz isi padu piksel yang rendah, manakala pendedahan dos radiasi yang tinggi pada pesakit telah dipilih bagi memperoleh imej untuk menghasilkan resolusi tinggi (Liedke et al. 2009). Walau bagaimanapun, dalam kajian ini, pilihan saiz isi padu piksel sedia ada adalah 0.076,0.1 dan 0.2 mm dengan Kodak 9000 3D; saiz isi padu piksel pada $0.2 \mathrm{~mm}$ telah dipilih kerana ia dianggap optimum untuk meminimumkan dos radiasi tetapi masih mencukupi daripada segi resolusi untuk mengukur penyerapan akar gigi. Tambahan pula, dos efektif CBCT yang digunakan dalam kajian ini telah dilaporkan oleh Pauwels et al. (2012) sebagai yang paling rendah (19 $\mu \mathrm{Sv})$ untuk kawasan gigi hadapan pada maksila. Berbanding unit СВCT yang lain yang boleh mencecah sehingga $652 \mathrm{u}$ Sv pada kawasan yang sama dengan bidang pandang rendah dan 1073 ųSv pada kawasan maksilofasial dengan bidang pandang tinggi (Li 2013).

Kejadian dan keterukan penyerapan akar gigi semasa rawatan ortodontik daripada kajian ini mempunyai persamaan dengan kajian sebelumnya. Lund et al. (2010) menganalisis imej CBCT daripada gigi insisor hingga ke molar pertama terhadap 152 pesakit dengan maloklusi kelas I. Dalam kajian itu, 94\% daripada pesakit mempunyai $\geq 1$ akar yang mengalami penyerapan akar melebihi $1 \mathrm{~mm}$ dan $6.6 \%$ mempunyai $\geq 1$ gigi mengalami penyerapan akar melebihi $4 \mathrm{~mm}$. Kajian ini menunjukkan kesemua gigi insisor daripada subjek kajian mengalami PAAL tetapi panjang akar yang diserap tidak melebihi $2.25 \mathrm{~mm}$ selepas 12 bulan rawatan ortodontik. Oleh itu, kejadian PAAL pada gigi insisor sepanjang tempoh rawatan ortodontik adalah tinggi namun tahap keterukan PAAL adalah rendah kerana penyerapan tidak melebihi 25\% panjang akar gigi (Kaley \& Phillips 1991).

\section{KESIMPULAN}

Berdasarkan pengukuran linear pada imej 3D CBCT, didapati kejadian PAAL meningkat dengan tempoh rawatan ortodontik (0 hingga 12 bulan). Perbandingan antara kumpulan gigi trauma dan gigi tanpa trauma mendapati tahap kejadian adalah sama pada tempoh rawatan ortodontik enam dan 12 bulan. Bagi tahap keterukan penyerapan akar gigi pula adalah sama di antara gigi yang mengalami trauma dengan gigi tanpa trauma bagi kedua tempoh rawatan ortodontik. Kajian ini mendapati, rawatan ortodontik adalah selamat dilakukan terhadap pesakit yang mempunyai sejarah trauma pada gigi.

\section{PENGHARGAAN}

Kami mengucapkan terima kasih kepada Kementerian Pengajian Tinggi Malaysia ke atas geran FRGS/1/2011/SG/ UKM/02/13 dan ERGS/1/2012/SKK11/UKM/02/5. Kami juga mengucapkan terima kasih kepada Universiti Kebangsaan Malaysia untuk geran DPP-2015-033.

\section{RUJUKAN}

Abass, S.K. \& Hartsfield, J.K. 2007. Orthodontics and external apical root resorption. Seminars in Orthodontics 13: 246-256.

Al-Qawasmi, R.A., Hartsfield, J.K., Everett, E.T., Flury, L., Liu, L., Foroud, T.M., Macri, J.V. \& Roberts, W.E. 2003. Genetic predisposition to external apical root resorption. American Journal of Orthodontics and Dentofacial Orthopeadics 123(3): 242-252.

Alqerban, A., Jacobs, R., Fieuws, S. \& Willems, G. 2011. Comparison of two cone beam computed tomographic systems versus panoramic imaging for localization of impacted maxillary canines and detection of root resorption European Journal of Orthodontics 33(1): 93-102.

Artun, J., Smale, I., Behbehani, F., Doppel, D., Van't Hof, M. \& Kuijpers-Jagtman, A.M. 2005. Apical root resorption six and 12 months after initiation of fixed orthodontic appliance therapy. Angle Orthodontist 75(6): 919-926.

Beck, B.W. \& Harris, E.F. 1994. Apical root resorption in orthodontically treated subjects: Analysis of edgewise and light wire mechanics. American Journal of Orthodontics and Dentofacial Orthopeadics 105(4): 350-361.

Brezniak, N., Goren, S., Zoizner, R., Dinbar, A., Arad, A., Wasserstein, A. \& Heller, M. 2004. A comparison of three methods to accurately measure root length. Angle Orthodontist 74(6): 786-791.

Brin, I., Tulloch, J.F.C., Koroluk, L. \& Philips, C. 2003. External apical root resorption in Class II malocclusion: A retrospective review of 1- versus 2-phase treatment. American Journal of Orthodontics and Dentofacial Orthopeadics 124(2): 151-156.

Castro, I., Valladares-Neto, J. \& Estrela, C. 2015. Contribution of cone beam computed tomography to the detection of apical root resorption after orthodontic treatment in root-filled and vital teeth. Angle Orthodontist 85(5): 771-776.

Castro, I.O., Alencar, A.H.G., Valladares-Neto, J. \& Estrela, C. 2013. Apical root resorption due to orthodontic treatment 
detected by cone beam computed tomography. Angle Orthodontist 83: 196-203.

Consolaro, A. \& Furquim, L.Z. 2014. Extreme root resorption associated with induced tooth movement: A protocol for clinical management. Dental Press Journal of Orthodontics 19: $19-26$

Da Silveira, H.L.D., Silveira, H.E.D., Liedke, G.S., Lermen, C.A., Dos Santos, R.B. \& De Figueiredo, J.A.P. 2007. Diagnostic ability of computed tomography to evaluate external root resorption in vitro. Dentomaxillofacial Radiology 36(7): 393-396.

Dudic, A., Giannopoulou, C., Leuzinger, M. \& Kiliaridis, S. 2009. Detection of apical root resorption after orthodontic treatment by using panoramic radiography and cone-beam computed tomography of super-high resolution. American Journal of Orthodontics and Dentofacial Orthopaedics 135: 434-437.

Erdinç, A.M.E. \& Dinçer, B. 2004. Perception of pain during orthodontic treatment with fixed appliances. European Journal of Orthodontics 26(1): 79-85.

Ericson, S. \& Kurol, J. 2000. Resorption of incisors after ectopic eruption of maxillary canines: ACT study. Angle Orthodontist 70(6): 415-423.

Esteves, T., Ramos, A.L., Pereira, C.M. \& Hidalgo, M.M. 2007. Orthodontic root resorption of endodontically treated teeth. Journal of Endodontics 33: 119-122.

Fox, N.2005. Longer orthodontic treatment may result in greater external apical root resorption. Journal of Evidence-Based Dental Practice 6(1): 21.

Galvão, M.C.d.S., Sato, J.R. \& Coelho, E.C. 2012. Dahlberg formula: A novel approach for its evaluation. Dental Press Journal of Orthodontics 17: 115-124.

Han, G., Huang, S., Hoff, J.W.V., Zeng, X. \& Kuijpers-Jagtmand, A.M. 2005. Root resorption after orthodontic intrusion and extrusion: An intraindividual study. Angle Orthodontist 75: 912-918

Kaley, J. \& Phillips, C. 1991. Factors related to root resorption in edgewise practice. Angle Orthodontist 61: 125-132.

Karkhanechi, M., Chow, D., Sipkin, J., Sherman, D., Boylan, R.J., Norman, R.G., Craig, R.G. \& Cisneros, G.J. 2013. Periodontal status of adult patients treated with fixed buccal appliances and removable aligners over one year of active orthodontic therapy. Angle Orthodontist 83(1): 146-151.

Kasiulevičius, V., Sapoka, V. \& Filipaviciute, R. 2006. Sample size calculation in epidemiological studies. Gerontologija 7(4): 225-231.

Leach, H.A., Ireland, A.J. \& Whaites, E.J. 2001. Radiographic diagnosis of root resorption in relation to orthodontics. British Dental Journal 190: 16-22.

Levander,E. \& Malmgren, O. 1988. Evaluation of the risk of root resorption during orthodontic treatment: A study of upper incisors. European Journal of Orthodontics 10(1): 30-38.

Li, G. 2013. Patient radiation dose and protection from conebeam computed tomography. Imaging Science in Dentistry 43(2): 63-69.

Liedke, G.S., da Silveira, H.E.D., da Silveira, H.L.D., Dutra, V. \& de Figueiredo, J.A.P. 2009. Influence of voxel size in the diagnostic ability of cone beam tomography to evaluate simulated external root resorption. Journal of Endodontics 35(2): 233-235.

Linge, B.O. \& Linge, L. 1983. Apical root resorption in upper anterior teeth. The European Journal of Orthodontics 5: 173-183.

Linge, L. \& Linge, B.O. 1991. Patient characteristics and treatment variables associated with apical root resorption during orthodontic treatment. American Journal of Orthodontics and Dentofacial Orthopeadics 99(1): 35-43.

Long, H., Zhou, Y., Pyakurel, U., Liao, L., Jian, F., Xue, J., Ye, N., Yang, X., Wang, Y. \& Lai, W. 2013. Comparison of adverse effects between lingual and labial orthodontic treatment: A systematic review. Angle Orthodontist 83(6): 1066-1073.

Lopatiene, K. \& Dumbravaite, A. 2008. Risk factors of root resorption after orthodontic treatment. Stomatologija, Baltic Dental and Maxillofacial Journal 10: 89-95.

Lund, H., Gröndahl, K. \& Gröndahl, H-G. 2010. Cone beam computed tomography for assessment of root length and marginal bone level during orthodontic treatment. Angle Orthodontist 80(3): 466-473.

Lupi, J.E., Handelman, C.S. \& Sadowsky, C. 1996. Prevalence and severity of apical root resorption and alveolar bone loss in orthodontically treated adults. American Journal of Orthodontics and Dentofacial Orthopaedics 109: 28-37.

Luther, F., Dominguez-Gonzalez, S. \& Fayle, S.A. 2005. Teamwork in orthodontics: Limiting the risks of root resorption. British Dental Journal 198: 407-411.

Malmgren, O., Goldson, L., Hill, C., Orwin, A., Petrini, L. \& Lundberg, M. 1982. Root resorption after orthodontic treatment of traumatized teeth. American Journal of Orthodontics 82(6): 487-491.

Maltha, J.C., Leeuwen, E.J.v., Dijkman, G.E.H.M. \& KuijpersJagtman,A.M. 2004. Incidence and severity of root resorption in orthodontically moved premolars in dogs. Orthodontics and Craniofacial Research 7: 115-121.

Mandall, N., Lowe, C., Worthington, H., Sandler, J., Derwent, S., Abdi-Oskouei, M. \& Ward, S. 2006. Which orthodontic archwire sequence? A randomized clinical trial. European Journal of Orthodontics 28: 561-566.

Martins, D.R., Tibola, D., Janson, G. \& Maria, F.R.T. 2012. Effects of intrusion combined with anterior retraction on apical root resorption. European Journal of Orthodontics 34: $170-175$.

Maués, C.P.R., Nascimento, R.R.D. \& Vilella, O.D.V. 2015. Severe root resorption resulting from orthodontic treatment: Prevalence and risk factors. Dental Press Journal of Orthodontics 20: 52-58.

Nanekrungsan, K., Patanaporn, V., Janhom, A. \& Korwanich, N. 2012. External apical root resorption in maxillary incisors in orthodontic patients: Associated factors and radiographic evaluation. Imaging Science in Dentistry 42(3): 147-154.

Oliveira, A.G.D., Consolaro, A., Junqueira, J.L.C., Martins-Ortiz, M.F. \& Franzolin, S.D.O.B. 2011. Analysis of predictors of root resorption in orthodontic treatment. Journal of Dentistry and Oral Hygiene 3: 46-52.

Owman-Moll, P. 1995. Orthodontic tooth movement and root resorption with special reference to force magnitude and duration. A clinical and histological investigation in adolescents. Swedish Dental Journal 105(Supplement): 1-45.

Patel, S., Dawood, A., Mannocci, F., Wilson, R. \& Ford, T.P. 2009 Detection of periapical bone defects in human jaws using cone beam computed tomography and intraoral radiography. International Endodontic Journal 42: 507-515.

Pauwels, R., Beinsberger, J., Collaert, B., Theodorakou, C., Rogers, J., Walker, A., Cockmartin, L., Bosmans, H., Jacobs, R., Bogaerts, R. \& Horner, K. 2012. Effective dose range for dental cone beam computed tomography scanners. European Journal of Radiology 81(2): 267-271.

Sameshima, G.T. \& Sinclair,P.M. 2001. Predicting and preventing root resorption: Part I. Diagnostic factors. American Journal 
of Orthodontics and Dentofacial Orthopeadics 119(5): 505-510.

Sanders, M.A., Hoyjberg, C., Chu, C.B., Leggitt, V.L. \& Kim, J.S. 2007. Common orthodontic appliances cause artifacts that degrade the diagnostic quality of CBCT images. Journal of the California Dental Association 35(12): 850-857.

Sherrard, J.F., Rossouw, P.E., Benson, B.W., Carrillo, R. \& Buschang, P.H. 2010. Accuracy and reliability of tooth and root lengths measured on cone-beam computed tomographs. American Journal of Orthodontics and Dentofacial Orthopeadics 137: 100-108.

Smale, I., Årtun, J., Behbehani, F., Doppel, D., Hof, M.V.T. \& Kuijpers-Jagtman, A.M. 2005. Apical root resorption 6 months after initiation of fixed orthodontic appliance therapy. American Journal of Orthodontics and Dentofacial Orthopaedics 128: 57-67.

Talic, N.F. 2011. Adverse effects of orthodontic treatment: A clinical perspective. The Saudi Dental Journal 23: 55-59.

Tecco, S., D’Attilio, M., Tetè, S. \& Festa, F. 2009. Prevalence and type of pain during conventional and self-ligating orthodontic treatment. European Journal of Orthodontics 31(4): 380-384.

Thomson, W.M. 2002. Orthodontic treatment outcomes in the long term: Findings from a longitudinal study of New Zealanders. Angle Orthodontist 72: 449-455.

Thongudomporn, U. \& Freer, T.J. 1998. Anomalous dental morphology and root resorption during orthodontic treatment: A pilot study. Australian Orthodontic Journal 15(3): 162-167.

Topkara, A., Karaman, A.I. \& Kau, C.H. 2012. Apical root resorption caused by orthodontic forces: A brief review and a long-term observation. European Journal of Dentistry 6: 445-453.

Tsiklakis, K., Donta, C., Gavala, S., Karayianni, K., Kamenopoulou, V. \& Hourdakis, C.J. 2005. Dose reduction in maxillofacial imaging using low dose cone beam CT. European Journal of Radiology 56(3): 413-417.

Tsuchiya, S., Tsuchiya, M., Nishioka, T., Suzuki, O., Sasano, Y. \& Igarashi, K. 2013. Physiological distal drift in rat molars contributes to acellular cementum formation. The Anatomical Record 296: 1255-1263.

Weiland, F. 2003. Constant versus dissipating forces in orthodontics: The effect on initial tooth movement and root resorption. European Journal of Orthodontics 25(4): 335-342.

Weltman, B., Vig, K.W., Fields, H.W., Shanker, S. \& Kaizar, E.E. 2010. Root resorption associated with orthodontic tooth movement: A systematic review. American Journal of Orthodontics and Dentofacial Orthopedics 137(4): 462-476.
Yu, J-H., Shu, K-W., Tsai, M-T., Hsu, J-T., Chang, H-W. \& Tung, K-L. 2012. A cone-beam computed tomography study of orthodontic apical root resorption. Journal of Dental Sciences 8(1): 74-79.

Shahrul Hisham Zainal Ariffin, Zulham Yamamoto \&

Sahidan Senafi

Pusat Pengajian Biosains dan Bioteknologi

Fakulti Sains dan Teknologi

Universiti Kebangsaan Malaysia

43600 UKM Bangi, Selangor Darul Ehsan

Malaysia

Ikmal Mohamad Jaafar \& Rohaya Megat Abdul Wahab*

Jabatan Orthodontik, Fakulti Pergigian

Universiti Kebangsaan Malaysia

Jalan Raja Muda Abdul Aziz

50300 Kuala Lumpur, Federal Territory

Malaysia

Zulham Yamamoto

Department of Histology, Faculty of Medicine

Universitas Sumatera Utara, Medan

Indonesia

Rus Dina Rus Din

Program Sains Forensik

Pusat Pengajian Sains Diagnostik dan Kesihatan Gunaan

Fakulti Sains Kesihatan

Universiti Kebangsaan Malaysia

Jalan Raja Muda Abdul Aziz

50300 Kuala Lumpur, Federal Territory

Malaysia

*Pengarang untuk surat-menyurat; email: shahroy7@gmail.com

Diserahkan: 15 Ogos 2016

Diterima: 8 Februari 2017 